\title{
The Perceptions of Small Business Owners on Tourism Development in the Blackstone Valley, Rhode Island
}

\author{
Samuel MENDLINGER ${ }^{1,3}$, Masaki MIYAKE ${ }^{1}$, Robert BILLINGTON ${ }^{1,2}$ \\ ${ }^{1}$ Department of Administrative Sciences, Metropolitan College, Boston University, 808 Commonwealth Ave., Boston MA, 02215, \\ USA; ${ }^{2}$ Blackstone Valley Tourism Council, 175 Main Street, Pawtucket, Rhode Island 02860, USA; ${ }^{3}$ corresponding author. \\ Email: mendling@bu.edu,m.miyake@gmail.com,BVRI@aol.com
}

Received March 28, 2009; revised May 25, 2009; accepted June 19, 2009.

\begin{abstract}
The Blackstone Valley Tourism Council (BVTC), a state designated council to promote tourism in the Blackstone Valley, Rhode Island, has led tourism development efforts for two decades to revitalize the economics and livability of place. This study examines the perception of small and medium enterprises (SMEs) in juxtaposition to the macro-regional level of tourism development as lead by the BVTC. Local SMEs foresee business opportunities via tourism, yet often do not fully recognize their potential role within it. Local government and the notion of civic tourism are also examined to further understand this gap. The study concludes that local community involvement still remains in the realm of participation rather than empowerment. Thus, the BVTC is being sought for a more innovative and strategic role to develop and manage tourism assets instead of the implementer role traditional tourism organizations engage in.
\end{abstract}

Keywords: SMEs, communication, BVTC, tourism development strategy

\section{Introduction}

Tourism has become a potential new industry for economically declining regions. Tourism can absorb labor, unused resources and improve the quality of life of residents $[1,2,3,4,5,6]$. Small to medium sized enterprises (SMEs), particularly those in small cities and towns, play a crucial role in economic development [7] and in tourism the majority of businesses are SMEs $[8,9,10,11]$.

The perceptions and opinions of SME business owners on the direction and implementation of tourism development strategies are important as they are usually the ones who develop and invest in new tourism opportunities. Therefore an understanding of their attitudes, believes, priorities, impressions and concerns is important for effective tourism destination planning and development. However, too often tourism development models exclude or minimize the role of SMEs due to the complexity of this group [12,13,14,15]. Yet, as Pistrui, et al., [16] and Freeman and McVea [17] point out, in most economies SMEs are at the forefront of socioeconomic development and in comparison to large businesses, SMEs in the long-run are much more likely to create new job opportunities as well as develop and implement new ideas $[18,19]$. It is important for SMEs to be included in the decision-making processes and their perceptions and objectives incorporated into tourism development strategies $[17,20]$. In addition we need to better understand the comprehension level of the assistance that SMEs receive from government (local, state and federal) and quasi-government organizations (e.g. visitor and tourism bureaus and councils) that support tourism development. This is especially important for smaller destinations who often bundle numerous secondary assets into a major tourism destination. This study examines these points in the Blackstone Valley of Rhode Island.

\section{Blackstone Valley and Tourism}

The Blackstone River Valley is a 400,000 acres region encompassing central Massachusetts and northern Rhode Island. The American Industrial Revolution began in the valley with the opening of the first water powered textile mill in 1793. This study focuses on tourism development in the nine Rhode Island communities of the Blackstone Valley: Burrillville, Central Falls, Cumberland, Glocester, Lincoln, North Smithfield, Pawtucket, Smithfield, and Woonsocket.

Beginning in the 20th century, Blackstone Valley's textile industry found itself migrating to the South where 
cheaper labor, lower taxes, anti-union laws and abundant cotton supplies was readily acquirable. By the mid-20th century, the Blackstone Valley was an economically and sociocultural depressed region with high unemployment, social instability and extensive environmental degradation. Since then, attempts have been made to find new industries for economic revival and tourism was one option. In 1986 the U.S. Congress designated the Blackstone Valley as a National Heritage Corridor in recognition of its historical significance. In a 1997 study, the Rhode Island Policy Council [21] acknowledged that the tourism sector has the potential to become a cluster market for the Blackstone Valley, but only if the State enhances accessibility and develops exciting attractions combined with the strong involvement and collaboration of the private sector to create a competitive market cluster.

The Blackstone Valley Tourism Council (BVTC), a state-designated and sponsored nonprofit organization, was established in 1985 to initiate and coordinate tourism asset development and marketing programs and activities aimed at economic development and job creation. It is responsible for creating and implementing a comprehensive regional sustainable tourism development plan to promote economic development via tourism within Blackstone Valley [22]. BVTC bases its approach on the geotourism and civic tourism model of place development which is aimed at improving the geographic, social and economic layers of a local community; i.e. to improve the quality of life of the local population via tourism [23]. It emphasizes the empowerment and well-being of the local community [24] and strengthening SMEs via community participation in order to allow for easier adoption of and transition to new ideas and opportunities $[20,25]$. The BVTC receives annually approximately $\$ 90,000$ from federal and state governments plus raises additional funds via tourism revenue, hotel room tax, and private and individual donation, to carry out the bulk of its operations. Total income and expenditure reported for fiscal year 2007 were \$1,056,350 and $\$ 1,081,850$ respectively [26]. The Blackstone Valley has a story to tell, the genesis of the American Industrial Revolution, and resources that visitors can enjoy (e.g. old factory buildings, nature and mixed cultural communities) but lacks a single primary tourism asset. Therefore the BVTC employs a micro-clustering strategy of bundling many assets throughout the Valley whose effectiveness is dependent on an active and aware SME community.

Today the Blackstone Valley annually hosts over a million tourists [23]. Tourism accounts for between 4 to $15 \%$ of total employment per community in 2006 [27] and tourism income in 2006 was $\$ 99$ million [28]. These figures indicate that tourism is positively impacting the economy of these communities. However we have a poor understanding of the perceptions of the business sector on the direction and implementation of tourism development and their opinion of BVTC's strategic model. In this study we examined: 1 ) what perceptions and opinions do SMEs have on the region's tourism development strategy; and 2) how do local businesses perceive the work of the BVTC and other government or quasi-governmental organizations in developing tourism opportunities. This will be useful for other communities as they develop their tourism industry.

\section{Research Methodologies}

Qualitative research methodology was used to assess the perceptions of local tourism business owners and others working in tourism on tourism development in the Blackstone Valley. We were interested in understanding their perceptions in five areas: 1) the local economic situation; 2) tourism; 3) the BVTC; 4) other government tourism programs and initiatives; and 5) business opportunities in tourism. In-depth semi-structured interviews were used to identify factors which affect residences' opinions and perceptions on the existing tourism industry [29,30,31,32]. Lepp [31] and Westwood [32] pointed out that this method allows for the injection of new and often unexpected ideas and allows the interviewees to freely express their points of view. Hernandez et al., [29] said that the main advantage of in-depth interviews is that a better understanding of respondents' thinking and attitudes on key issues could be obtained than with structured interviews. A 14 group question questionnaire was created and asked to all interviewees (Table 1). If needed up to 10 follow up questions were asked per interviewee (we believed that more than 24-25 questions may produce the point of diminishing returns in respect to quality answers).

Nineteen people were interviewed, sixteen who represented different types of SMEs involved in the tourism industry and three government officials involved in tourism industry development, in the nine Blackstone Valley communities (Table 2). We randomly selected 20 potential SME candidates using the member list from the Northern Rhode Island Chamber of Commerce [33] and three government officials; all but four agreed to be interviewed. Government officials were included not only to act as reference sources on programs and initiatives geared towards local tourism related businesses, but also as measuring points to identify any inconsistency between the private and public sectors' perceptions. With the exception of two, all interviewees held positions 
Table 1. The fourteen question groups asked to all interviewees

1 The Blackstone Valley region has experienced severe economic decline after its textile industry moved to the South. Can you describe what type of economic models did your community use for economic development? Do you see tourism as a vehicle for such development?

2 Can you please tell me what your organization does in tourism? Why was it established? What is your position?

3 Please list the strongest economic sectors in the Blackstone Valley. Where do you place tourism? Do you see this list changing in the future?

4 What kind of government initiatives and funding support the local tourism industry?

5 What percentage of your tourism business relies on local vendors?

6 Is your business affected by seasonality in tourism visitation?

7 The Blackstone Valley Tourism Council is responsible for promoting tourism in the region in various ways, from direct activities, such as festivals and tours to indirect activities such as real estate development. Have you established a relationship with the Blackstone Valley Tourism Council, and if so please describe it? Have they had an impact on your business? If so, how? What is your opinion of the BVTC?

8 Tell me about the impact of tourism, both good and bad, on your community.

9 What type of support is your tourism business receiving from the local/state/federal government?

10 Do you think the approach, such as taxation programs, development programs, job generation programs, that the local government is taking on old mills and buildings is effective? Do you think the local community will benefit from this? Do you think they can do more?

11 How does your town differentiate its tourist assets in comparison to neighboring towns and regions?

12 How do you find the tourism infrastructure system in your area? Is it efficient? Do you think out-of-town visitors find it useful?

13 If you were to make any changes to the current tourism model of the BVTC, what would it be and why?

14 Would you continue to invest in tourism, and why?

Table 2. The Background of the Interviewees

\begin{tabular}{llll}
\hline Interviewee Code & Sector & Location & Gender \\
\hline AB \#1 & Agriculture & Cumberland & Female \\
AB \#2 & Agriculture & North Smithfield & Female \\
RL \#1 & Tourism and leisure & Lincoln & Male \\
RL \#2 & Tourism and leisure & Pawtucket & Female \\
RL \#3 & Tourism and leisure & Woonsocket & Male \\
RL \#4 & Tourism and leisure & Pawtucket & Female \\
GT \#1 & Government & Burrillville & Male \\
GT \#2 & Government & Pawtucket & Male \\
GT \#3 & Government & Woonsocket & Male \\
LB \#1 & Lodging & Glocester & Male \\
LB \#2 & Lodging & Pawtucket & Male \\
LB \#3 & Lodging & Woonsocket & Male \\
RE \#1 & Real estate & Lincoln & Female \\
RT \#1 & Restaurant & Woonsocket & Male \\
MG \#1 & Manufacturing \#1 & Cumberland & Male \\
RB \#1 & Retail business \#1 & Cumberland & Male \\
RB \#2 & Retail business \#2 & Glocester & Male \\
RB \#3 & Retail business \#3 & Woonsocket & Female \\
RB \#4 & Retail business \#4 & Woonsocket & Male \\
\hline
\end{tabular}


which involved decision-making in their respective organizations. All interviews occurred between November 1 and December 6, 2007. We conducted all of the interviews and interviewees. The interviews were digitally recorded (averaged approximately 30 minutes) and transcribed verbatim. Thematic analysis and triangulation were used by the authors to gain insights into the answers [34].

\section{Themes from the Interviews}

We grouped the themes that emerged into five categories: 1) Tourism Development and Economic Growth; 2) Blackstone Valley Tourism Council; 3) Aid from Federal, State and Local Governments for Tourism Development; 4) Business Development; and 5) Cooperation among stakeholders.

\subsection{Tourism Development and Economic Growth}

After experiencing years of economic depression, most businesses are beginning to see positive changes in the region:

\section{- "I think we are seeing evolution. I think it will be more gradual, but I see possibilities to grow and prosper.” (RL \#1)}

Most interviewees said that tourism has become an important economic sector in the Blackstone Valley. Many specifically mentioned two area that the BVTC has emphasized over the years: 1) historical and heritage tourism with phrases such as "a lot of history," "a bit of history," "heritage tourism" and "incredible amount of historical value" commonly used by the interviewees; and 2) recently developed tourism activities or assets, e.g. the boat tours, the museums, arts festivals and walking tours. When interviewees were asked if they anticipated tourism playing a major economic role in the future, opinions gravitated between 'having potential' and 'remaining at the present state,' although several from more rural, low tourism areas, said that it was "non-existent" or "not visible" in their respective communities but was in others. Interestingly, several business owners from Pawtucket and Woonsocket, where tourism assets are well developed and accessible, questioned the existence of a glass ceiling which limits tourism's growth:

- "We are a developing area. Now the question is will we be able to keep it together? Will it come and go? I am not quite sure." (LB \#3)

A recurring theme was the underdeveloped main streets or downtown areas and the crucial role these play in a community:
- "I guess they need to push it in this area. It needs to be more developed, especially the Downtown area. If you want to bring tourists in, you've got to have something for them to do, and I don't think we have." (LB \#2)

- "(Main Street redevelopment) kind of reverberated out to trying to, because the mill center was vacant, and it's still vacant today. That's the biggest focus of what we are redeveloping. Begin in the heart of the town. It's the town's face and identity, but it starts building there, and aims to recapture what was constructed to make things work.” (GT \#1)

These comments center on the still insufficient activities for local residents and tourists. Several interviewees emphasized that it was indispensable for maintaining the integrity of place and hoped that the Blackstone Valley would not be weighed down with amusement park type attractions.

The survey also found that the level of comprehension on what tourism entails differed among interviewees. The majority linked tourism to business opportunities and economic enhancement. However, a few classified the sector as sightseeing activities for leisure visitors, separating business-related visitors from the tourist category. Below is a quote from a lodging business describing its type of guests:

- "I have three kinds of business: tourism business, business and third is, what I would call, "businessthat-I-would-have-gotten-no-matter-wherever-I-am.” (LB \#3)

It also appears that some local residents are not fully aware of the degree of tourism development. For example:

- “...the locals are oblivious to tourism. As a matter of fact, when they find out that I am a bed and breakfast operator, they say, "In Woonsocket, you have a bed and breakfast?” (LB \#3)

This lodging business further commented that unless they were directly involved in a tourism business, they would not have been aware that such a sector existed.

\subsubsection{Investing in Tourism}

Nearly every local business interviewed who is involved in tourism commented that they would continue to invest in tourism. Many foresee new business opportunities and are aware that if properly developed and marketed tourism can have substantial economic impact on their business and communities. However several interviewees stated that they would continue to do so only as long as there was return on investment: 
- "All we need to do is create vehicles (tourism assets such as textile mills and waterfalls)...for example to bring the people over here, and once the people come, I think business will also come, but business are not going to invest money if they see they are not getting positive results.” (MG \#1)

- "I would continue as far as marketing dollars and what not... but you can only invest in what you are going to see a return on, so as long as you can see a financial return then you continue to do that." (AB \#2)

Government officials similarly backed this providing that there is sufficient funding. All government officials said that they were doing as much as they could possibly do to support the region's economic development as well as the efforts of the BVTC:

- 'I can't say that it's (tourism) bad. Because if anything, I mean hopefully we will see more of it in the future. It'd be nice to have another bed-and-breakfast here and there. That's something I would like to try to see, and encourage the sector.” (GT \#1)

\subsubsection{Public Transportation}

The general consensus on the transportation infrastructure in the Blackstone Valley was "good" or "fairly good" but several pointed out that improvements still need to be made. For instance, one lodging manager pointed out that it was not easy to navigate visitors through the Blackstone Valley's transportation system, nor could they rely on taxis as their services were poor. The interviews highlighted that the majority of visitors visited the region used their own vehicle while only a small percentage using public transportation. One business owner recognized the importance of infrastructural development in their community:

- "We are tiny for any type of public transportation, but if we did have the train, boy, would our community grow even more.” (RB \#3)

According to one government official, discussions have been held on developing a more visitor- and environment-friendly transportation system in the Blackstone Valley. Although public awareness is still relatively low on this particular subject, the development and implementation efforts of bike paths and pedestrian-friendly streets are widely recognized by the interviewees.

\subsubsection{Security and Safety}

In recent years, issues on security and safety have become important in the tourism industry. An interviewee said:

- “I don't feel comfortable sending somebody (guest) down that way (downtown area), because there's really nothing open at night, and I don't think it's safe.” (LB \#2)

\subsection{Blackstone Valley Tourism Council}

Opinion on the work and accomplishments of the BVTC is mostly positive. Interviewees acknowledge and recognize the organization's efforts to rebuild the region's economy and image, particularly their strength in tourism advocacy. Many businesses expressed a sense of trust in their operations and initiatives and an appreciation in BVTC's transparency. Phrases such as "great asset," “active,” “innovative,” “very involved,” and "wonderful” were used to describe the organization:

- "I do follow the activities of the Blackstone Valley Tourism Council and they are very active.” (LB \#3)

- "We are proud to be part of the Blackstone Valley, and we think highly of the organization.” (RL \#1)

- “...we have an organization like Blackstone Valley Tourism Council which has been very, very successful in raising the profile of the Valley.” (GT \#3)

\subsubsection{Partnership}

The majority of interviewees said that their businesses had established some form of partnership, or are in the process of establishing one, with the BVTC:

- “...there is visibility such as vehicles, brochures, newsletter, Guide to the Blackstone Valley, e-mail newsletters which is very effective, a group sales person at their office...they (BVTC) have a lot of marketing vehicles, have the capability to utilize those things in a monumental way to the assets in this City and all of the Blackstone Valley. I love to see them utilize those assets more.” (RL \#2)

- "They (BVTC) are a great help and assistance as we don't have to do it. They do the marketing for us." (AB \#1)

However, some criticisms were expressed. One lodging owner (LB \#1) said that the organization's promoting and marketing activities with him were not as beneficial as originally anticipated and no follow-up communication was established between the two entities. Others expressed a sense of the limitations of the BVTC's operational capabilities and goals:

- “...We've been trying to establish a relationship with them (BVTC), a marketing relationship with them...They've been unreliable... We've sent them our press releases, it doesn't get into their publications...I think they are focused on their own events, and not on their partnerships with organizations like us. We directly conflict.” (RL \#2) 
- “...stretched thin with his (Bob Billington, president of BVTC) job, duties and teachings, and everything that he has to do. He is not as accessible as he should be." (GT \#2)

- "I do establish a relationship with them and they established a relationship with me, but I am a dot on a large circle for them. They have a much broader focus, and they should." (LB \#3)

Most interviewees acknowledged the leadership and support of the BVTC in the region's tourism sector. The following are three examples:

- "There's...an old farmhouse in town, probably the most rural part of town.. Bob and I worked together to make a zoning change, to make it legal, to make it all happen. So that's a very small scaled...small propriety owner example of how, but how we can think of one little piece of tourism...” (GT \#1)

- "I am in the process of doing that (establishing a relationship with BVTC). So you know, why do it. I would like to see my community grow, and to see my business grow." (RB \#3).

- "...they (BVTC) have an advertising opportunity coming up that we will probably be taking advantage of it as well. It will be in a magazine and they are very active staying in contact with local businesses, so through emails and mailings that kind of things, so we are always paying attention and reading what they are send us, and if it's something that works for us, we get involved." ( $\mathrm{AB} \# 2)$

\subsubsection{Changes}

The majority of interviewees commented that the current BVTC's tourism geotourism model should continue:

- "Make any changes? That's a hard one. No, it's so hard to answer something like that. I wouldn't make any changes. I would just keep going with what they (BVTC) are doing, and making it better... and what I mean by that is...you keep going with the same effort that they have, and I think they are going to achieve good positive results..." (MG \#1)

- “Well, I wouldn't change a thing. I think they (BVTC) have a pretty good handle on things. It's hard just to get people to visit this Blackstone Valley. It's not an easy sell...where you know Newport or Cape Cod, you've got the beaches. You work what you have basically." (RT \#1)

Nevertheless the interviewees did express the need for changes to improve tourism development and wanted the BVTC to help implement these changes. The changes were:
1) More support and funding from State government

2) Enhance marketing and promotional strategies

3) Communication transparency

4) Enhance public transportation in the region

5) Further develop present attractions and add new ones

6) Retain the John H. Chafee Blackstone Valley National Heritage Corridor Commission

Most interviewees had the first two items as the most important. The third item is a key in keeping the local community involved in the region's economic development, as the following quote shows:

- "We are developing. We do communicate with each other along the Valley, but there needs to be a little more...I guess, "crystallization," is a good word. We are still working, we are working together, we are more aware of each other now than we've ever were, and by the way, we never thought of ourselves living in the Blackstone Valley. We all lived in different communities, do you get my drift? Now we are beginning to think of ourselves as living in this Valley... and each one of us has a story to tell." (RL \#3)

Partnership with the BVTC also led businesses into establishing 'sub-partnerships' amongst themselves. For instance, a lodging business located in Woonsocket described having established partnerships with businesses like the Museum of Work and Culture and local restaurants as a way to not only enhance their businesses, but also to present a hospitable ambient to visitors.

\subsection{Aid from Federal, State and Local Govern- ments for Tourism Development}

There was strong agreement among interviewees that for tourism development, while the BVTC was doing as much as it could, most Federal and State funding for tourism development was funneled to the two major tourist destinations in Rhode Island, Providence and Newport, and very little to the Blackstone Valley. In addition many believed that the bed tax which is supposed to fund tourism development did not help them as much as it could.

- "They (BVTC) are doing so much, and they are doing everything I think that can possibly be done. I give them an A+ for their efforts. I can't think of anything to do that they haven't already done. It would be nice if the State of Rhode Island could get as actively involved in promoting tourism in the Blackstone Valley" ( $\mathrm{RB} \# 2$ )

- "...how can tourism grow in the area when there isn't a funding mechanism that can be tapped? I know that 
the Blackstone Valley Tourism Council tries to get money from the State, from the bed tax. It does get some money from the State, but not enough money as compared to Newport." (LB \#3)

Government officials interviewed agreed that the amount of public funding for tourism development was insufficient:

- "We could do more... we could do more financially. We would like to have more development funding for startup projects, where we have in the past been successful in leveraging several federal funding so that the leverage ratio was 20 to 1 . So from relatively modest funding we can through our partnerships really get a lot more money pumped into redeveloping mills or other economic activities." (GT \#3)

This official noted that they would like to see tourism evolve where it can be self-sustained since "ultimately it is an economic activity," and not dependent on "seed money from non-profits or heritage programs".

In spite of the lack of support at the state and federal level, several local businesses acknowledged the efforts made by their respective local governments:

- "...I can't complain with the economic development office because they certainly have been a huge help... it was through them that I learned about the arts and entertainment tax exempt thing and the grant for the signage.” (RB \#3)

- "Everything reasonably been kind of successful because we've had consistent leadership and support (from local government), politics never really made it into the frame and mess things up. I don't know if you talk about politics at all, but it's important." (GT \#1)

\subsection{Business Development}

Most interviewees perceived tourism business opportunities in the region. Several commented that they had either recently started a new tourism business or enhanced their businesses operations and utilized local government programs and the BVTC's marketing resources.

- “...certainly Pawtucket is one, especially in the arts. With all the studios that they have created in the old mills... they are extremely impressive...so I would say that Pawtucket has certainly done their homework. And these are communities that have struggled like Woonsocket that are really...kind of coming out with a renewed face." (RB \#3)

- "We need to start more restaurants in our cities." (GT \#2)

Several interviewees pointed out that problems exist in developing tourism related businesses within the Black- stone Valley region. Several believe that there is insufficient funding for an economic development plan, much less develop a tourism industry:

- "There's not a lot of agencies out there willing to give a helping hand. To give them better tax or tax incentives and things like that. There not much for the little guy...” (RE \#1)

- "I think financial backing to attract tourism businesses is needed." (RB \#3)

There is a sense among the interviewees that unless the business is involved in the arts, farming or other government-led initiative, not many options are available to encourage small-scale tourism businesses to develop.

\subsection{Cooperation Among Stakeholders}

Problems in cooperation and communication between government and the private sector were expressed by many interviewees. Many local businesses were unable to clearly define one government initiative or program outside of the BVTC which seriously supports the tourism industry in the region:

- "Probably a better question for tourism folks...I guess, in a nice way of saying, we don't receive the incentives that other industries would." (RL \#1)

The two most referred programs were the hotel taxation program (the bed tax) and the arts initiative program.

- “...we have a $6 \%$ room tax, and that's supposed to help tourism... What we get for our $6 \%$ is some maps I think.” (LB \#1)

- "Particularly the current Mayor...has put in place with his department of planning and redevelopment several initiatives, some of them even groundbreaking for the State, groundbreaking for the area, such as tax incentives for artists in several different areas of the city, where artists can sell their work and the buyers are not required to pay sales tax." (RL \#2)

Government officials realized that lack of communication exists when it comes to informing the local community about their programs:

- "But I don't think that some of the older people understand the benefits of what is happening with the arts and it all sort of rests on our shoulders. We have to communicate better about the positive impact that will ultimately impact them." (GT \#2)

- "...one question I have is that we are recently trying to keep the economic development agencies involved in the discussion, but it is not clear to me that they, even though they talk about how important tourism is, that they actively and very directly participate in 
promoting tourism.” (GT \#3)

- "I think there was a big push for a while. The current administration has taken a back seat towards tourism.” (RE \#1)

\section{Discussion}

Despite the importance of the tourism industry for Blackstone Valley's economic development, we found two areas of concern. First, the low level of comprehension by some interviewees about governmental support programs for tourism development. Second, there appears to be a subtle discrepancy between the vision of the BVTC, which is based on a macro regional level, and the vision of local businesses, which is based on a more micro local level.

Interviewees who do not directly benefit from the hotel tax allocation fund or from BVTC programs rarely mentioned other government support or incentive programs for tourism development available through local or state governments. A problem may be that these programs are not offered through a single umbrella program but rather by different departments, e.g. planning, economic development or community development. This may create difficulties in the process of how local businesses perceive and understand government support programs. In a study by Palmer and Bejou [35] on American and British tourism destination marketing alliances (DMA), e.g. Visitor and Convention Bureaus (VCBs) and Tourism Development Action Program (TDAPs) organizations (comparable to BVTC), notes that funding is affected by how organizations were formed and structured. In the United States, the majority of collaborative stakeholders partnering with these organizations do not directly fund them, but taxation and business revenue are the main funding sources; SMEs are more recipients of support than partners in tourism development programs. In the United Kingdom stakeholders play a direct role in supporting and funding these organizations and as such are closely involved with development planning. Consequently feedback, communication and accessibility between SMEs and governmental officials and organizations are greater in the UK than in the American model. Although the BVTC is not a VCB by definition, it shares a similar organizational structure; thus, in 2006 funding was obtained through program revenue (40\%), hotel occupancy tax (30\%), and ticket sales and store revenue (1\%) [26].

Two interviewees in this study revealed that economic development agencies are keen about tourism, yet their involvement and promotional efforts are weak. In 1997, the Rhode Island Policy Council (RIPC) presented a re- port which provided analysis and recommendations on emerging economic sectors, including tourism [21]. The report showed that the management segment of the tourism infrastructure is layered by organizations devoted to their regional tourism promotion and development activities, but lack the flexibility to collaborate in a state-level policy development and implementation scheme. It notes that local businesses perceived that the "overall problem is that neither the State nor the regional tourism promotion agencies adequately listen or are responsive to their needs" [21]. Brunetto and Farr-Wharton [12] argue that SMEs place great importance on issue of trust when deciding on government programs. This strongly reiterates the issue of communication and accessibility.

RIPC recommends that the state's tourism development efforts should be actively led by the private sector in order to diffuse bureaucratic problems as well as providing this sector ownership of the efforts [21]. From the perceptions obtained from our interviewees, it is clear that not all local businesses have the same degree of understanding and/or involvement in the region's tourism development scheme. In a 2003 policy report, the European Commission found that SMEs have a tendency to not readily communicate their views to the government due to their lack of time and resources deriving from their small operations which leads to their low involvement in policy and law making [36]. This led the European Union to create an environment for SMEs to actively participate in community policy making, reducing bureaucratic layers, modifying laws and establishing “one-stop-shops" to reduce administrative costs [36]. Thomas and Thomas [37] state that local businesses will naturally become involved in influencing local policies if their operations are closely linked to the region's future, and vice versa. Their case study on the community of Saltaire, Bradford, England, found that "local micro-enterprises for all their success in liaising with agencies do not possess the wealth of the resources that can assist effective policy mobilization” [37].

The definition of small business in Rhode Island is "one that has 30 or fewer full-time employees, or has $\$ 1$ million or less in gross receipts” [38]. Szivas [39] notes that starting a tourism business is relatively easy as no formal education or skill set is required and can be pursued with low capital. Most of the SMEs participating in this study consisted of less than 10 employees and many do not have the expertise and/or financial resources to undertake marketing and promotional efforts. As a result they rely on the BVTC's well-established promotional marketing and distribution services. Much of BVTC's operations are based on developing and im- 
plementing tourism programs and activities, yet the perceptions stated by both local businesses and local government officials indicate that BVTC's services are being sought in a more collaborative and facilitating role. Local governments see the need for BVTC's presence and tourism expertise at the decision-making level, while local businesses, particularly those involved in tourism event implementation, seek this through collaboration. Although to date, BVTC has worked in various capacities, the survey suggests that its model is placing strain on the organization's resources. If continued, this could lead to stagnant results for the Blackstone Valley tourism industry. Frustration and disappointment by local businesses is beginning to surface.

Today for many communities, tourism is being used for economic regeneration. Bahaire and Elliott-White [40] note that when a local community perceives itself as being the tourism 'product,' as in civic or geo-tourism, empowerment and participation is imperative in realizing a self-sustaining industry. Yet, they argue that this scenario has led communities to play a vouching role for the sole purpose of commercial growth. This situation was found to a certain extent in this study (GT \#1). It has been argued that the participation of all stakeholders is unrealistic due to the difference in objectives that each may have [40]. However, Billington [22] notes that such synchronization can occur in the tourism industry when all sectors of the community adhere to social responsibility; i.e. tourism equates to being a collective effort. This was the BVTC's model during the initial revitalization of the Blackstone Valley. The question now is how synchronization can continue in a growing economy.

This study found that Blackstone Valley tourism related businesses have to some degree established partnerships not only with the BVTC, but also with other businesses. As explained by one leisure business, its developing of partnerships with several restaurants and retail stores in its vicinity has not only created business opportunities but believes these will further increase in the future. This practice has expanded the concept of tourism in the community. However, the survey found that partnerships are usually limited to businesses in interrelated sectors, such as lodging, restaurants, leisure facilities and amenity suppliers. For example, one real estate business distanced itself from 'tourism' businesses as it felt that no relevancy or benefits could be perceived or gained from them. Perhaps the match between real estate and tourism may seem unproductive at first, yet it can not be neglected that hidden opportunities exist, such as working with tourism to not only promote properties, but also the "livability" of the destination. This was found by Tsundoda and Mendlinger [41] in Peterborough
New Hampshire were real estate businesses view tourists as potential customers. This situation takes us back to the original argument on the comprehension level by local businesses in reference to the region's economic development plan and vision via tourism. Lack of comprehension could potentially hinder the exploration and exploitation of new business opportunities.

\section{Conclusions}

The BVTC's tourism development strategy for the Blackstone Valley has helped to produce a tourism industry where none existed before. For the most part the local business community is very supported of the organization and supports it direction. However we did find three potentially worrying issues:

(a) communication between business owners and government officials - the problems associated with communication between business owners and government officials is most apparent in the lack of awareness or understanding by a number of business owners on availability of local government funding for tourism development when such funds are available. Regardless of the causes and faults of this issue, it has produced a degree of resentment.

(b) government funding - the lack of strong government financial support, especially at the state and federal level, is perceived by the business community to hinder tourism development as opposed to other state destinations, e.g. Newport and Providence, which they believe receive more funding from the state.

(c) future of the BVTC - a number of interviewees expressed the possible need as tourism increases for the BVTC to rethink its strategic role in developing and managing tourism assets.

In respect to these issues we are making 4 recommendations for strengthening the present environment for local businesses and the BVTC, with the ultimate objective to create a self-sustaining and viable tourism industry for the future:

\subsection{Shifting of Roles}

As the tourism industry matures the BVTC may wish to shift from tourism asset development, coordination and implementation to a more tourism asset facilitator role. This will alleviate the BVTC staff from implementing and managing time consuming projects and activities to concentrate in strategic planning, while simultaneously strengthening collaborative partnerships with local businesses by transferring 'ownership' or management of assets. In order to further shift their role, it may be feasible for the BVTC to develop a system based on licensing 


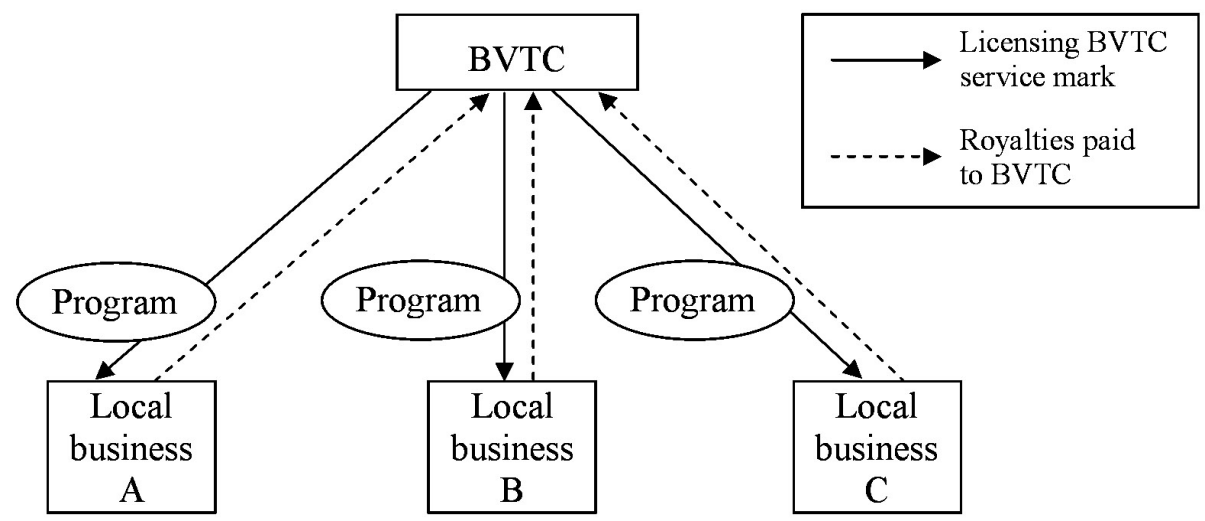

Figure 1. Program licensing model for the BVTC

their services and programs to interested parties, and in return, the designated parties pays royalty fees to the BVTC (Figure 1) [42]. This will reduce BVTC's human resource constraint while protecting the program's mission and funding. In addition, this may be coupled with the development of tourism entrepreneurship programs which will be discussed under the fourth recommendation.

\subsection{Strengthening Advocacy}

The aim is to provide SMEs in tourism a strong advocate for a better and fair business environment. Underfunded programs seem to have hindered development or existence of some local businesses. As the BVTC has effectively advocated on behalf of local businesses on key issues such as zoning and fire regulations in the past (see GT \#1), this role should become more important as tourism grows.

\subsection{Improving Communication}

There is a need to develop a better communication strategy and/or framework for bridging the gaps between the public and the private sectors. This issue was frequently referred to in the survey by both local businesses and government officials. Strengthening BVTC's role in communication between different entities can lead to improved efficiency, consistency and transparency.

\subsection{Educational Programs}

There is a need to improve the entrepreneurial skills of local businesses which in turn should help raise the quality of tourism businesses and products throughout the Blackstone Valley region. The study showed that local businesses search for guidance on day-to-day operations and business development. The BVTC has provided consultation to startups on a one-to-one basis, ultimately considered for support if the business is foreseen as one with staying power. The BVTC may wish to develop a tourism entrepreneurship education program which can simultaneously function for networking and entrepreneurial morale.

\section{REFERENCES}

[1] Michael, E. J. (2006). Developing cluster. In E. J. Michael (Ed.), Micro-clusters and networks: the growth of tourism, Kidlington, United Kingdom: Elsevier, Ltd., 21-32.

[2] Crouch, G. I. \& Ritchie, J. R. B. (1999). Tourism, competitiveness, and societal prosperity. Journal of Business Research, 44, 137-152.

[3] Fainstein, S. \& Gladstone, D. (1999). Evaluating urban tourism. In D. Judd and S. Fainstein (Eds.), The Tourist City. New Haven, CT: Yale University Press, 21-34.

[4] Tooman, L. A. (1997). Applications of the life-cycle model in tourism. Annals of Tourism Research, 24, 214-234.

[5] Naisbitt, J. (1994). Global paradox: The bigger the world economy, the more powerful its smallest players. New York, NY: William Morrow \& Co.

[6] Law, C. M. (1992). Urban tourism and its contribution to economic regeneration. Urban Studies, 29, 599-618.

[7] U.S. Census Bureau. (2007). Facts for Features: Small business week 2006. (No. CB06-FFSE.03). Washington, DC.

[8] Gavron, R., Cowling, M., Holtham, G. \& Westall, A. (1998). The Entrepreneurial Society. London: Institute for Public Policy Research.

[9] Shaw, G. \& Williams, A. (1994). Critical issues in tourism: A geographical perspective. Oxford: Blackwell.

[10] Riley, M. (1986). Some social and historical perspective on unionization in the U.K. hotel industry. International Journal of Hospitality Management, 14, 99-104. 
[11] Diamond, J. (1977). Tourism's role in economic development: The case reexamined. Economic Development and Cultural Change, 25, 539-553.

[12] Brunetto, Y. \& Farr-Wharton, R. (2007). The moderating role of trust in SME owner/managers' decision-making about collaboration. Journal of Small Business Management, 45, 362-387.

[13] Morrison, A. \& Teixeira, R. (2004). Small business performance: A tourism sector focus. Journal of Small Business and Enterprise Development, 11, 166-173.

[14] Thomas, R. (2000). Small firms in the tourism industry: Some conceptual issues. International Journal of Tourism Research, 2, 345-353.

[15] Page, S. J., Forer, P. \& Lawton, G. R. (1999). Small business development and tourism: Terra Incognita? Tourism Management, 20, 435-459.

[16] Pistrui, D., Welsh, H. P., Pohl, H. J., Wintermantel, O. \& Liao, J. (2003). Entrepreneurship in the new Germany. In A. Watson, D. \& A. Kirby (Eds.), Small Firms and Economic Development in Developed and Transition Economies: A Reader. Hampshire, UK: Ashgate Publishing Ltd., 115-130.

[17] Freeman, E. \& McVea, J. (2001). A stakeholder approach to strategic management. in M. Hitt, E. Freeman, and J. Harrison (Eds.). Handbook of Strategic Management. Oxford: Blackwell Publishing.

[18] Schaffhauser, A. (2005). Entrepreneurship and economic growth. Minnesota Economic Trends, http://www.deed. state.mn.us/lmi/publications/trends/1105/growth.htm.

[19] Hjalager, A. (1999, August). Tourism destinations and the concept of industrial districts. Poster session presented at the European Regional Science Association (ERSA) Conference. Dublin, Ireland.

[20] Tosun, C. \& Timothy, D. J. (2003). Arguments for community participation in the tourism development process. The Journal of Tourism Studies, 14, 2-15.

[21] Rhode Island Policy Council, RIPC. (1997). Chapter 12: Travel and tourism. In Meeting the Challenge of the New Economy - 1997 (207-227). Retrieved September 27, 2007 from http://www.ripolicy.org/resources/content/challenge.html.

[22] Billington, R. D. (2004). Federal leverage attracts private investment in industrial historic sites: A case study. International Journal of Heritage Studies, 10, 349-359.

[23] Blackstone Valley Tourism Council, BVTC. (2007a). Annual Report to the Community. [Brochure]. Pawtucket, RI: Author.

[24] Holecek, D. \& Fridgen, J. (2002). Geo-Tourism: The new hyphenated tourism. Michigan Tourism Business, 1.

[25] Cole, S. (2006). Information and empowerment: The keys to achieving sustainable tourism. Journal of Sustainable Tourism, 14, 629-644.

[26] Blackstone Valley Tourism Council, BVTC. (2007b). Annual work plan 2007. Retrieved September 27, 2007 from http://www.blackstonevalleytourismcouncil.com/ workplan.htm.

[27] Rhode Island Economic Development Corporation, RIEDC. (2007a). State and community profiles. http:// www. riedc.com/riedc/ri_databank/31/.

[28] Travel Industry Association. (2006). Economic impact of domestic travel on the main nine communities of the Blackstone Valley at Rhode Island in 2004. Washington, D.C.

[29] Hernandez, S. A., Cohen J., \& Garcia H. L. (1996). Residents' attitudes towards an instant resort enclave. Annals of Tourism Research, 23, 755-779.

[30] Kayat, K. (2002). Power, social exchanges and tourism in Langkawi: Rethinking resident perceptions. International Journal of Tourism Research, 4, 171-191.

[31] Lepp, A. (2007). Residents' attitudes towards tourism in Bigodi village, Uganda. Tourism Management, 28, 876885.

[32] Westwood, S. (2007). What lies beneath? In I. Ateljevic, A. Pritchard and N. Morgan (Eds.) The Critical Turn in Tourism Studies: Innovative Research Methodologies, Oxford, United Kingdom: Elsevier Ltd., 292-316.

[33] Northern Rhode Island Chamber of Commerce. (2007). Member directory. http://norhodeislandricoc.weblinkconnect.com/CWT/External/WCPages/WCDirectory/Directo ryStartPage.aspx.

[34] Herman, S. \& Egri, C. P. (2002). Triangulation in action: Integration of qualitative and quantitative methods to research environmental leadership. In Parry, K.W. and Meindl, J.R. (Eds) Grounding Leadership Theory and Research: Issues, Perspectives and Methods. Grennwich, CT. Information Age Publishing, 129-148.

[35] Palmer, A. \& Bejou, D. (1995). Tourism destination marketing alliances. Annals of Tourism Research, 22, 616-629.

[36] European Commission. (2003). Thinking small in an enlarging Europe. Brussels, Belgium.

[37] Thomas, R. \& Thomas, H. (2006). Micro politics and micro firms: A case study of tourism policy formation and change. Journal of Small Business and Enterprise Development, 13, 100-114.

[38] Rhode Island Economic Development Corporation, 
RIEDC. (2007b). Rhode Island business incentives - August 2007. http://www.riedc.com/files/RI_Business_Incentives.pdf.

[39] Szivas, E. (2001). Entrance into tourism Entrepreneurship: A UK case study. Tourism and Hospitality Research, 3, 163-172.

[40] Bahaire T. \& Elliott-White, M. (1999). Community participation in tourism planning and development in the historic City of York, England. Current Issues in Tourism, 2(2\&3), 243-276.

[41] Tsundoda, T. and S. Mendlinger (2009). Economic and social impact of tourism on a small town: Peterborough New Hampshire. Journal of Service and Management 2, 61-70.

[42] Beshel, B. (2001). An introduction to franchising. New York, NY: IFA Educational Foundation. 